\title{
Adult/juvenile interactions of infaunal bivalves: contrasting outcomes in different habitats
}

\author{
Simon F. Thrush*, Judi E. Hewitt, Rick D. Pridmore, Vonda J. Cummings \\ National Institute of Water and Atmospheric Research, PO Box 11-115, Hamilton, New Zealand
}

\begin{abstract}
Field experiments were used to assess the influence of density variations of adult bivalves on recruitment of juveniles. The generality of these results was tested by running the experiment concurrently at 2 sites of different sediment grain size and wave exposure. Adults of 2 bivalve species, the deposit-feeding tellinid Macomona liliana and the suspension-feeding venerid Austrovenus stutchburyi, were used in the experiment. The experiment consisted of 14 treatments of various combinations of densities of live adults or the empty articulated shells of the 2 species. Three species of juvenile bivalve ( $M$. Liliana, A. stutchburyi and Nucula hartvigiana) were sampled from the experiment on 3 occasions over a $9 \mathrm{wk}$ period. Treatment effects were consistent over time, but reflected only small changes in the mean density of juvenile bivalves. The presence of empty articulated shells of adult $M$. Lliana or $A$. stutchburyi, positioned at localities within the sediment which reflected normal living conditions, had no detectable influence on the density of juvenile bivalves. Treatments involving adult $A$. stutchburyi influenced only the density of juvenile conspecifics at the muddy-sand site. Treatments involving adult $M$. liliana produced significant effects on the density of both $M$. liliana and $N$. hartvigiana juveniles at both sites. However, these effects occurred in opposite directions at the 2 sites. At the muddy-sand site, highest juvenile densities were associated with high adult densities, but, at the sandy site, they were associated with the absence of adult $M$. liliana. The identification of subtle density changes at the sandy site was unexpected because sediment transport is frequent at this site and associated passive movement of juveniles has the potential to mask local biotic interactions. The change found in the direction of interactions between adult and juvenile bivalves between sites has implications for the generality of such interactions: in particular it highlights the influence that habitat may have on ecological interactions.
\end{abstract}

KEY WORDS: Adult/juvenile interactions Bivalve molluscs - Habitat variations Suspension feeders Deposit feeders . New Zealand

\section{INTRODUCTION}

The potential importance of interactions between established adults and settling larvae to population and community dynamics has long been recognised in marine soft-bottom communities (Thorson 1950, Mileikovsky 1969). A variety of interactions between established adults and juveniles can be demonstrated, including: ingestion of recruits (e.g. Woodin 1974, Ambrose 1984), interference by bioturbation (e.g. Brenchley 1981, Elmgren et al. 1986), modification of local flow patterns by physical structures (e.g. Eckman 1985) or feeding currents (e.g Ertman \& Jumars 1988, Andre et al. 1993), provision of refugia from predation

·E-mail: thrush@eco.cri.nz (e.g Luckenbach 1987, Peterson \& Black 1993), and the release of detectable chemical cues (e.g. Butman et al. 1988, Woodin 1991). In order to identify generalities in adult/juvenile interactions, many studies have characterised animals according to modes of feeding, mobility or bioturbation. In a recent review of experimental studies, 'Olafsson et al. (1994) noted that density-dependent inhibition of recruitment by adult deposit feeders has been frequently documented, while the effects on recruits of adult suspension feeders have been found to be less consistent. However, many studies have noted problems with generalities based on functional aggregations due to the specifics of animal biology (Weinberg 1984, Hines et al. 1989, 'Olafsson 1989, Posey 1990).

Habitat differences may also have an important influence on the outcome of adult/juvenile interactions 
(Peterson 1982, 'Olafsson 1989, Ahn et al. 1993). Differences in habitat, particularly changes in sediment type, usually reflect changes in a variety of factors (see Snelgrove \& Butman 1994 for recent review). For example, there is generally a close relationship between sediment grain size and hydrodynamic forces, with coarser sediments prevalent in the more dynamic environment. Hydrodynamic processes in turn influence larval supply which provides a framework for subsequent interactions amongst the benthos (Butman 1987, Woodin 1991, 'Olafsson et al. 1994).

Hydrodynamics may also influence the density and mobility of post-larval stages. Many infaunal species exhibit secondary dispersal and settlement behaviour (Baggerman 1953, Muus 1973, Beukema 1973, Sigurdsson et al. 1976, Martel \& Chia 1991, Armonies \& Hellwig-Armonies 1992, Cummings et al. 1993). Particularly on beaches and sandflats where wind-waves and tidal currents may disturb sediments, small surface-dwelling infauna are likely to be transported (e.g Tamaki 1987, Emerson \& Grant 1991. Thrush et al 1991, Commito et al. 1995, Cummings et al. 1995). In fact, for near-surface-dwelling juvenile bivalves movement with sediment bedload or as resuspended particles appears inevitable when hydrodynamic forces are sufficient to create moving sediment ripples (Roegnar et al. 1995). Such potentially high rates of post-settlement movement could conceivably mask local biotic interactions.

This study builds on previous work by assessing the importance of small-scale adult/juvenile interactions amongst infaunal bivalves at 2 sites that differ in windwave exposure and sediment characteristics. At each site we tested the influence of density variation in adult bivalves of 2 common but functionally different species (i.e. the tellinid Macomona liliana and the venerid Austrovenus stutchburyi) on the recruitment of juvenile bivalves. If the transport of juvenile bivalves is a major factor differentiating between locations, we expected to be able to detect local biotic interactions only in the low energy environment.

\section{METHODS}

Study sites. The study was conducted on the extensive intertidal flats near Wiroa Island in Manukau Harbour $\left(37^{\circ} 02^{\prime} \mathrm{S}, 174^{\circ} 41^{\prime} \mathrm{E}\right)$, New Zealand. The 2 experimental sites spanned the range of sediment grain size in which Macomona liliana and Austrovenus stutchburyi co-occur. Sediment grain size characteristics for each site are given in Table 1 . The sandy site was composed predominantly of well compacted fine sand with $3 \%$ of the sediment in the silt/clay fraction. The muddy-sand site was composed of a surface $(0$ to $5 \mathrm{~cm})$
Table 1 Characteristics of sediments from the sandy and muddy-sand sites. Data presented are mean $\pm \mathrm{SD}(\mathrm{n}=6)$ for sediment samples of 0 to $10 \mathrm{~cm}$ depth. Methods follow Folk (1968)

\begin{tabular}{|lrr|} 
& \multicolumn{1}{c}{ Sandy } & Muddy-sand \\
\hline Median grain size $(\Phi)$ & $2.61 \pm 0.09$ & $3.35 \pm 0.16$ \\
Sorting & $0.43 \pm 0.12$ & $1.97 \pm 0.18$ \\
Skewness & $0.12 \pm 0.13$ & $0.65 \pm 0.24$ \\
Kurtosis & $1.33 \pm 0.29$ & $0.64 \pm 0.24$ \\
Percent sand & $96.99 \pm 0.82$ & $76.36 \pm 2.52$ \\
Percent mud & $3.02 \pm 0.82$ & $23.64 \pm 2.56$ \\
\hline
\end{tabular}

layer of uncompacted muddy sediments over a layer of sand, shell hash and clay. The top $10 \mathrm{~cm}$ of sediment from this site exhibited a median grain size of very fine sand with about $23 \%$ of the sediment in the silt/clay fraction. The sandy site was exposed to the prevailing southwesterly winds with a fetch of $15 \mathrm{~km}$ (at high tide), while the muddy-sand site was sheltered by Wiroa Island and exposed only to the north and east with a fetch of $<1 \mathrm{~km}$ (at high tide). The 2 sites were situated about $1 \mathrm{~km}$ apart. Each site was situated at about mid-tide level, but the muddy-sand site was submerged about 30 min longer per tide than the sandy site. Manukau Harbour has semi-diurnal tides with mean neap and spring tidal ranges of 2.0 and $3.4 \mathrm{~m}$ respectively.

Species. Macomona liliana and Austrovenus stutchburyi are the 2 most common bivalves living in the sandflats of Manukau Harbour (Pridmore et al. 1990). Adult $M$. liliana live about 3 to $7 \mathrm{~cm}$ below the sediment surface and are generally siphonal surfacedeposit feeders (although under some conditions they may also suspension feed). A. stutchburyi, however, live with the anterior portion of the shell protruding just above the sediment surface and suspension feed through a short inhalant siphon.

In early January 1991,254 cores $\left(78.5 \mathrm{~cm}^{2} \times 10 \mathrm{~cm}\right.$ depth) were collected in the vicinity of each of the experimental sites. In this preliminary survey, adult Macomona liliana (20 to $30 \mathrm{~mm}$ long) were found at mean densities $( \pm \mathrm{SD})$ of $1.67( \pm 1.08)$ per core at the sandy site and $0.75( \pm 0.58)$ at the muddy-sand site. Mean densities $( \pm$ SD) of adult $A$. stutchburyi (20 to $30 \mathrm{~mm}$ long) were $2.37( \pm 1.64)$ and $3.87( \pm 2.33)$ at the sandy and the muddy-sand sites, respectively. From this preliminary survey, we determined the 3 densities of adult Macomona $\left(0,5\right.$ and 20 ind. per $\left.415 \mathrm{~cm}^{2}\right)$ and adult Austrovenus $\left(0,12\right.$ and 48 ind. per $\left.415 \mathrm{~cm}^{2}\right)$ to be used in the experiment. The middle density used for each species fell within $1 \mathrm{SD}$ of the mean found for both sites. The higher density represented that encountered in high-density patches on the flats, and was therefore calculated from whichever site had the 
highest density. These high densities fell within the 90th percentile of the preliminary samples at the sandy site for $M$. liliana and the muddy-sand site for $A$. stutchburyi. High densities of empty $M$. liliana and $A$. stutchburyi shells (20 and 48 whole shells per $415 \mathrm{~cm}^{2}$, respectively) were used to enable us to discriminate between the active effects of live bivalves and the physical effects of their shells. We were particularly interested in the potential of empty articulated $A$. stutchburyi shells to influence boundary flow and sediment stability or to provide a refuge from predators. Similar comparisons have been made in other experiments to separate the physical effects of bivalve shells from any biological activity (Peterson \& Andre 1980 , Black \& Peterson 1988, Peterson \& Black 1993).

Experimental design. The experiment was set up over $4 \mathrm{~d}$ in late January and early February 1991. This time of year is usually associated with high levels of recruitment for both Macomona liliana and Austrovenus stutchburyi (authors' unpubl. data). At each site, the experiment consisted of 14 treatments of various combinations of densities of live adults or empty articulated shells (Table 2), with 6 replicates per treatment. We did not include all possible combinations of empty $M$. liliana shells in the experiment because they were not considered likely to contribute to the interpretation of the experiment. Under normal living conditions $M$. liliana shells are buried about $7 \mathrm{~cm}$ below the sediment surface. At each site, treatment replicates were arranged in a randomized complete block design; the blocks were separated by $6 \mathrm{~m}$ and within blocks each treatment was separated by $1 \mathrm{~m}$. Each replicate plot consisted of $415 \mathrm{~cm}^{2}$ of natural bottom sediments surrounded by a plastic tube $(23 \mathrm{~cm}$ diameter $)$. The plastic tube was buried in the sediment with its top about $1 \mathrm{~cm}$ below the sediment surface and its bottom about $21 \mathrm{~cm}$ deep in the sediment. Sediment from within the tube was extracted and dry sieved on a $4 \mathrm{~mm}$ mesh to remove large $M$. liliana and $A$. stutchburyi, empty shells and large shell fragments. The sediment was then returned to the plot. At the muddy-sand site, care was taken to re-establish the layers of clay, sand/shell hash and surface muddy sand. Live adult $M$. Liliana and $A$. stutchburyi and articulated empty shells, all in the 20 to $30 \mathrm{~mm}$ size range, were collected from sediments in the vicinity of the experimental sites. The live bivalves were placed in an approximately regular array on the surface sediments of the experimental plots and allowed to burrow into the sediments. All empty shells were also arranged in an approximately regular array in their natural orientation. Empty A. stutchburyi shells were positioned so that the anterior margin of the shell protruded about 1 $\mathrm{mm}$ above the sediment surface. Empty $M$. liliana shells were positioned about $7 \mathrm{~cm}$ below the sediment surface.

One day after the initiation of the experiment, both Macomona feeding tracks and Austrovenus were observed in the plots to which they had been added. No dead bivalves were observed on the surface of any plot. Within $3 \mathrm{~d}$, sediments in the experimental plots could not be visually distinguished from the surrounding sediments. Numbers of $M$. liliana feeding tracks and $A$. stutchburyi observed in each replicate plot over the course of the experiment were consistent with treatment used. The absence of ray feeding pits, and hammered shells (indicative of shorebird predation), at the experimental sites indicates that predation on large bivalves was not important during the experiment.

Samples were collected from each replicate plot at each site 3,6 and $9 \mathrm{wk}$ after the initiation of the experiment. On each sampling occasion, 1 core $\left(1.8 \mathrm{~cm}^{2} \times\right.$ $2 \mathrm{~cm}$ depth) was collected from each plot. To prevent the core holes from influencing local hydrodynamics, they were filled with sediment that had been previously collected from the vicinity of each site and which had been sieved (500 $\mu \mathrm{m}$ mesh) and defaunated by freezing. After collection, core samples were fixed in a solution of $5 \%$ buffered formalin and $0.1 \%$ Rose Bengal in seawater. Samples were then sieved on a $180 \mu \mathrm{m}$ screen to extract juvenile bivalves, which were then sorted, identified and counted. Juvenile bivalves were defined as individuals 200 to $500 \mu \mathrm{m}$ in length. Both Macomona liliana and Austrovenus stutchburyi initially settle out of the water column at about $200 \mu \mathrm{m}$ in length, and grow to $500 \mu \mathrm{m}$ long within about 3 mo (M. Taylor pers comm.). Juveniles of only 3 bivalve species (i.e. M. liliana, A. stutchburyi and Nucula hartvigiana) were found in sufficient numbers to warrant statistical analysis.

Statistical analyses. The data were not analysed as a continuous function of changing density because the effect of 'shell only' treatments on juvenile bivalve

Table 2. Matrix of experimental treatments used at each site as defined by the number of adult bivalves (or empty shells) added to each $415 \mathrm{~cm}^{2}$ plot. M: Macomona liliand; A: Austrovenus stutchburyi; -: treatment not used; subscript $s$ represents the addition of empty articulated shells of the appropriate species. All additions (i.e. live bivalves and empty articulated shells) were 20 to $30 \mathrm{~mm}$ in length

\begin{tabular}{|lcrrr|}
\hline $\begin{array}{l}\text { Macomona } \\
\text { liliana }\end{array}$ & \multicolumn{5}{c}{ Austrovenus stutchburyi } \\
\hline 0 & 0 & 12 & 48 & 48 empty shells \\
5 & $0 M 0 A$ & $0 M 12 A$ & $0 M 48 A$ & $0 M 48 A_{\mathrm{s}}$ \\
20 & $5 M 0 A$ & $5 M 12 A$ & $5 M 48 A$ & $5 M 48 A_{\mathrm{s}}$ \\
20 empty shells & $20 M 0 A$ & $20 M 12 A$ & $20 M 48 A$ & $20 M 48 A_{\mathrm{s}}$ \\
& - & $20 M_{\mathrm{s}} 12 \mathrm{~A}$ & $20 M_{\mathrm{s}} 48 \mathrm{~A}$ & - \\
\hline
\end{tabular}




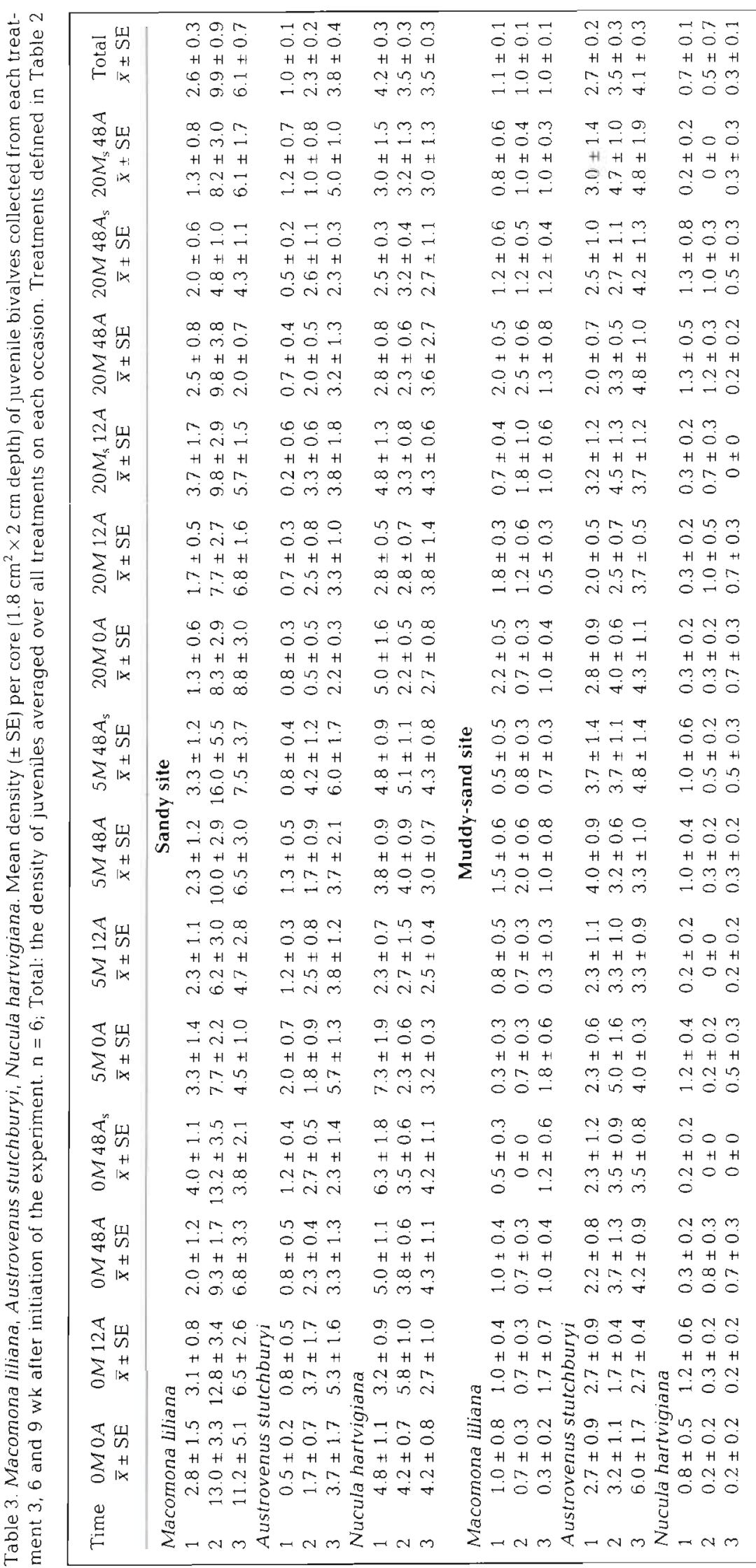

density could not a priori be determined relative to the effect of different densities of live adult bivalves. As indicated in Table 2, shells were thus considered to be a level within the factors of densities of adult Macomona liliana and Austrovenus stutchburyi. All analysis was performed using Proc GLM (SAS 1989).

Densities of juvenile Macomona liliana, Austrovenus stutchburyi and Nucula hartvigiana were initially analysed using a randomised complete block repeated-measures 3 way ANOVA (Crowder \& Hand 1990, Green 1993). The density of adult $M$. liliand, the density of adult A. stutchburyi and site were treated as fixed factors, while block was treated as a random factor nested within site. Data were log transformed $[\ln (x+0.1)]$ in order to satisfy the assumptions of homogeneity of variance ( $F$-max test). A sphericity test was used to test that all pairwise covariances among different times were equal. Where this assumption of independence of errors could not be met, the probability levels for $F$ were adjusted by the Huynh-Feldt (1976) method.

Subsequent to this, the densities of individual species from each treatment replicate were time averaged by summing the density on the 3 sampling occasions and dividing by 3. ANOVAs on these time averaged data were then carried out separately for each site, with the density of adult. Macomona liliana and the density of adult Austrovenus stutchburyi treated as fixed factors and block as a random factor. Multiple comparison tests (SNK) were performed where necessary to identify specific differences between factor levels. To assess the magnitude of the effects identified by these site-specific ANOVAs, a figure was constructed for each fixed factor showing the density of each species of juvenile bivalve $(\bar{x} \pm \mathrm{SE})$ at each level. The power of the site-specific ANOVAs to identify significant effects was assessed following Cohen (1988). 
Table 4. Macomona liliana, Austrovenus stutchburyi, Nucula hartvigiana. Results of repeated-measures ANOVA conducted on juvenile bivalve densities from both sites. The ANOVA table for each species is presented in 2 parts, the upper part in which time does not contribute to any effect and the lower part in which time contributes to every effect (Green 1993). As the assumption of a type $\mathrm{H}$ covariance structure is rejected for the analyses of $M$. liliana and $N$. hartvigiana juveniles ( $\mathrm{p}=0.045, \mathrm{p}=0.01$ respectively), the probability levels for $F$ given for these 2 species have been adjusted by the Huynh-Feldt (1976) method. df: degrees of freedom. M: Macomona factor. A: Austrovenus factor

\section{RESULTS}

Mean densities of juvenile Macomona liliana, Austrovenus stutchburyi and Nucula hartvigiana recorded in each treatment on each occasion at each site are presented in Table 3. Averaged over all treatments, juvenile A. stutchburyi exhibited the lowest variation in density across the 2 habitats. Interpretation of Table 3 is difficult due to the complexity of the experiment.

As the repeated-measures ANOVA identified at least 1 significant site $\times$ treatment interaction for each species of juvenile bivalve (Table 4), the only results discussed from this table are those involving the block and time factors. The effect of block (nested within site) was significant for Macomona liliana and Austrovenus stutchburyi juveniles, suggesting the spatial distributions of juveniles were influenced by larger-scale (10s of $\mathrm{m}$ ) processes. Significant time terms for each species of juvenile bivalve demonstrated that the density changed over the experimental period, although not necessarily in the same way at each site (significant time $\times$ site effects for $M$. liliana). However, the lack of significant time $\times$ treatment interactions suggests that even when densities of juveniles changed significantly their response to the treatments was consistent.

The significant interaction terms involving site found for each species of juvenile bivalve led us to analyse the responses of the 3 juvenile bivalve species to the treatments at each site separately. These analyses were performed on data averaged over time for each treatment replicate, as the lack of significant time $x$ treatment interactions in the repeated-measures ANOVA indicated it was possible to do this without loss of information.

At the sandy site, the density of juvenile Macomona liliana was significantly influenced by the manipulation of adult conspecifics or their empty shells (Table 5). The multiple comparison tests revealed a significant contrast between treatments with 20 adult $M$. liliana added and those with no adult $M$. liliana (Fig. 1). The highest density of juvenile $M$. liliana was

\begin{tabular}{|c|c|c|c|c|c|}
\hline Source & $d f$ & MS & $\begin{array}{c}\text { Error } \\
\text { MS }\end{array}$ & $F$ & $\mathrm{p}>F$ \\
\hline \multicolumn{6}{|l|}{ Macomona liliana } \\
\hline Site & 1 & 839.780 & 24.415 & 34.40 & 0.0001 \\
\hline Block (Site) & 10 & 25.825 & 4.831 & 5.35 & 0.0001 \\
\hline$M$ & 3 & 14.637 & 4.831 & 3.03 & 0.0319 \\
\hline$A$ & 3 & 2.362 & 4.831 & 0.49 & 0.6905 \\
\hline$M \times A$ & 7 & 9.128 & 4.831 & 1.89 & 0.0764 \\
\hline Site $\times M$ & 3 & 13.320 & 4.831 & 2.76 & 0.0451 \\
\hline Site $\times A$ & 3 & 15.478 & 4.831 & 3.20 & 0.0255 \\
\hline Site $\times M \times A$ & 7 & 2.001 & 4.831 & 0.41 & 0.8920 \\
\hline Error & 128 & 4.831 & & & \\
\hline Time & 2 & 48.982 & 4.531 & 10.81 & 0.0001 \\
\hline Time $\times$ Site & 2 & 30.068 & 4.531 & 6.64 & 0.0016 \\
\hline Time $\times$ Block (Site) & 20 & 4.370 & 4.531 & 0.96 & 0.5060 \\
\hline Time $\times M$ & 6 & 7.922 & 4.531 & 1.75 & 0.1103 \\
\hline Time $\times A$ & 6 & 6.420 & 4.531 & 1.42 & 0.2084 \\
\hline Time $\times M \times A$ & 14 & 3.709 & 4.531 & 0.82 & 0.6485 \\
\hline Time $\times$ Site $\times M$ & 6 & 6.760 & 4.531 & 1.49 & 0.1812 \\
\hline Time $\times$ Site $\times A$ & 6 & 7.783 & 4.531 & 1.72 & 0.1172 \\
\hline Time $\times$ Site $\times M \times A$ & 14 & 5.087 & 4.531 & 1.12 & 0.3378 \\
\hline Error (Time) & 256 & 4.531 & & & \\
\hline \multicolumn{6}{|c|}{ Austrovenus stutchburyi } \\
\hline Site & 1 & 142.628 & 15.630 & 9.13 & 0.0001 \\
\hline Block (Site) & 10 & 16.477 & 3.888 & 4.24 & 0.0001 \\
\hline M & 3 & 6.009 & 3.888 & 1.55 & 0.2060 \\
\hline A & 3 & 2.315 & 3.888 & 0.60 & 0.6192 \\
\hline$M \times A$ & 7 & 3.259 & 3.888 & 0.84 & 0.5581 \\
\hline Site $\times M$ & 3 & 1.547 & 3.888 & 0.40 & 0.7548 \\
\hline Site $\times A$ & 3 & 16.880 & 3.888 & 4.34 & 0.0060 \\
\hline Site $\times M \times A$ & 7 & 3.329 & 3.888 & 0.86 & 0.5432 \\
\hline Error & 128 & 3.888 & & & \\
\hline Time & 2 & 112.96 & 3.930 & 28.74 & 0.0001 \\
\hline Time $\times$ Site & 2 & 11.304 & 3.930 & 2.88 & 0.0582 \\
\hline Time $\times$ Block $($ Site $)$ & 20 & 4.770 & 3.930 & 1.21 & 0.2427 \\
\hline Time $\times M$ & 6 & 3.502 & 3.930 & 0.89 & 0.5021 \\
\hline Time $\times A$ & 6 & 4.156 & 3.930 & 1.15 & 0.3343 \\
\hline Time $\times M \times A$ & 14 & 3.154 & 3.930 & 0.80 & 0.6602 \\
\hline Time $\times$ Site $\times M$ & 6 & 4.478 & 3.930 & 1.14 & 0.3399 \\
\hline Time $\times$ Site $\times A$ & 6 & 6.702 & 3.930 & 1.71 & 0.1201 \\
\hline Time $\times$ Site $\times M \times A$ & 14 & 3.430 & 3.930 & 0.87 & 0.5583 \\
\hline Error (Time) & 256 & 3.930 & & & \\
\hline \multicolumn{6}{|l|}{ Nucula hartvigiana } \\
\hline Site & 1 & 1585.901 & 5.256 & 301.73 & 0.0001 \\
\hline Block (Site) & 10 & 5.314 & 4.451 & 1.19 & 0.3012 \\
\hline$M$ & 3 & 3.616 & 4.451 & 0.81 & 0.4893 \\
\hline A & 3 & 2.560 & 4.451 & 0.57 & 0.6326 \\
\hline$M \times A$ & 7 & 10.787 & 4.451 & 2.42 & 0.0231 \\
\hline Site $\times M$ & 3 & 19.064 & 4.451 & 4.28 & 0.0065 \\
\hline Site $\times A$ & 3 & 5.440 & 4.451 & 1.22 & 0.3045 \\
\hline Site $\times M \times A$ & 7 & 3.732 & 4.451 & 0.84 & 0.5575 \\
\hline Error & 128 & 4.451 & & & \\
\hline Time & 2 & 12.083 & 3.661 & 3.30 & 0.0384 \\
\hline Time $\times$ Site & 2 & 1.500 & 3.661 & 0.41 & 0.6641 \\
\hline Time $\times$ Block (Site) & 20 & 4.471 & 3.661 & 1.22 & 0.2352 \\
\hline Time $\times M$ & 6 & 5.643 & 3.661 & 1.54 & 0.1652 \\
\hline Time $\times A$ & 6 & 5.001 & 3.661 & 1.37 & 0.2288 \\
\hline Time $\times M \times A$ & 14 & 4.322 & 3.661 & 1.18 & 0.2902 \\
\hline Time $\times$ Site $\times M$ & 6 & 2.035 & 3.661 & 0.56 & 0.7653 \\
\hline Time $\times$ Site $\times A$ & 6 & 1.073 & 3.661 & 0.29 & 0.9398 \\
\hline Time $\times$ Site $\times M \times A$ & 14 & 4.328 & 3.661 & 1.18 & 0.2891 \\
\hline Error (Time) & 256 & 3.661 & & & \\
\hline
\end{tabular}


Table 5. Macomona liliana, Austrovenus stutchburyi, Nucula hartvigiana. Site-specific ANOVAs of juvenile bivalve densitues averaged over time. df: degrees of freedom. M: Macomona factor. A: Austrovenus factor

\begin{tabular}{|c|c|c|c|c|c|c|c|c|c|c|}
\hline \multirow[t]{2}{*}{ Source } & \multicolumn{5}{|c|}{ Sandy site } & \multicolumn{5}{|c|}{ Muddy-sand site } \\
\hline & $\mathrm{df}$ & MS & $\begin{array}{c}\text { Error } \\
\text { MS }\end{array}$ & $F$ & $\mathrm{p}>F$ & df & $\mathrm{MS}$ & $\begin{array}{c}\text { Error } \\
\text { MS }\end{array}$ & $F$ & $\mathrm{p}>F$ \\
\hline \multicolumn{11}{|c|}{ Macomona liliana } \\
\hline Block & 5 & 4.050 & 0.283 & 14.30 & 0.0001 & 5 & 2.895 & 0.780 & 3.71 & 0.0052 \\
\hline$M$ & 3 & 0.952 & 0.283 & 3.36 & 0.0239 & 3 & 2.652 & 0.780 & 3.40 & 0.0229 \\
\hline$A$ & 3 & 0.121 & 0.283 & 0.43 & 0.7328 & 3 & 1.277 & 0.780 & 1.64 & 0.1894 \\
\hline$M \times A$ & 7 & 0.572 & 0.283 & 2.02 & 0.0657 & 7 & 0.719 & 0.780 & 0.92 & 0.4952 \\
\hline Error & 65 & 0.283 & & & & 64 & 0.780 & & & \\
\hline \multicolumn{11}{|c|}{ Austrovenus stutchburyi } \\
\hline Block & 5 & 1.357 & 0.431 & 3.15 & 0.0132 & 5 & 1.712 & 0.133 & 12.85 & 0.0001 \\
\hline$M$ & 3 & 0.806 & 0.431 & 1.87 & 0.1435 & 3 & 0.217 & 0.133 & 1.63 & 0.1912 \\
\hline$A$ & 3 & 0.647 & 0.431 & 1.50 & 0.2222 & 3 & 0.448 & 0.133 & 3.36 & 0.0239 \\
\hline$M \times A$ & 7 & 0.471 & 0.431 & 1.09 & 0.3788 & 7 & 0.021 & 0.133 & 0.16 & 0.9921 \\
\hline Error & 65 & 0.431 & & & & 64 & 0.133 & & & \\
\hline \multicolumn{11}{|c|}{ Nucula hartvigiana } \\
\hline Block & 5 & 1.175 & 0.170 & 6.92 & 0.0001 & 5 & 0.055 & 0.190 & 0.29 & 0.9150 \\
\hline$M$ & 3 & 0.702 & 0.170 & 4.14 & 0.0096 & 3 & 0.730 & 0.190 & 3.84 & 0.0136 \\
\hline A & 3 & 0.178 & 0.170 & 1.05 & 0.3773 & 3 & 0.113 & 0.190 & 0.59 & 0.6210 \\
\hline$M \times A$ & 7 & 0.246 & 0.170 & 1.45 & 0.2003 & 7 & 0.403 & 0.190 & 2.12 & 0.0561 \\
\hline Error & 65 & 0.170 & & & & 64 & 0.190 & & & \\
\hline
\end{tabular}

found in treatments without adult $M$. liliana. Significant differences in the density of juvenile Austrovenus stutchburyi as a result of the experimental treatments at the sandy site were not detected. The density of juvenile Nucula hartvigiana again varied significantly with the level of the $M$. liliana factor, exhibiting a response to treatment levels similar to that of juvenile
M. liliana (Fig. 1). Block effects were apparent for each of the 3 species of juvenile bivalves (Table 5).

At the muddy-sand site, the density of Macomona li1iana juveniles was also significantly influenced by variations in the density of adult conspecifics or their empty shells (Table 5). However, effects opposite to those found in the sandy site were apparent, with low-

\section{SANDY SITE}

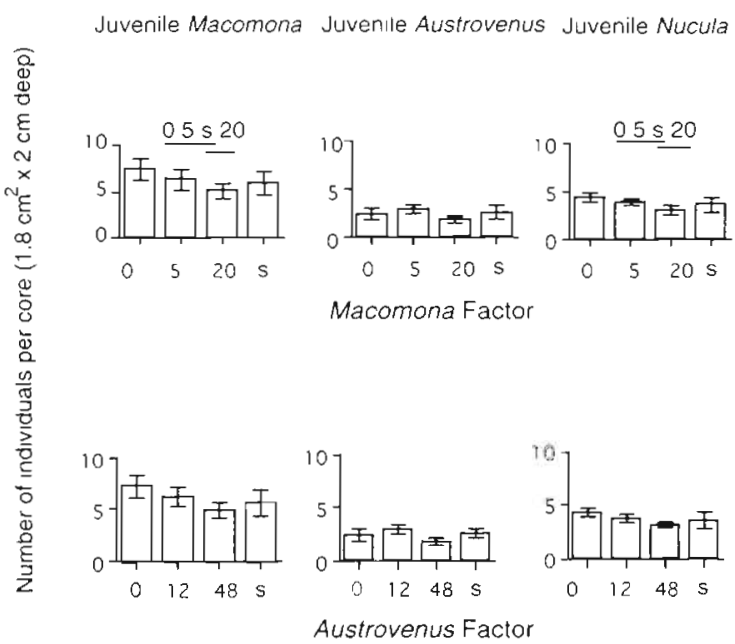

\section{MUDDY-SAND SITE}
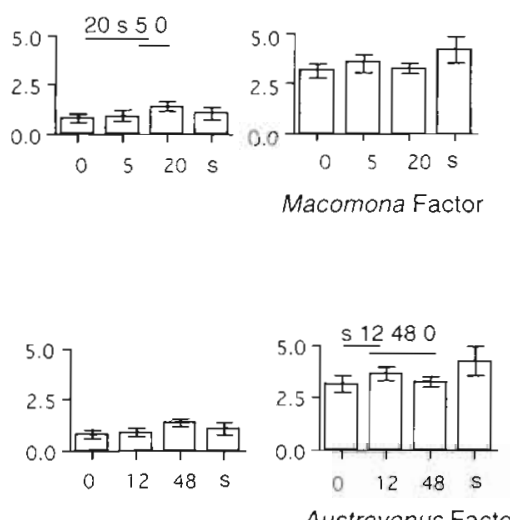
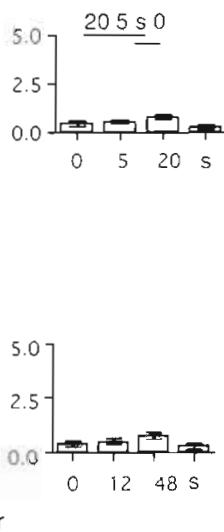

Fig. 1. Macomona Iiliana, Austrovenus stutchburyi, Nucula hartvigiand. Density of bivalve juveniles ( $\bar{x} \pm S E)$ found at each level of each fixed factor at each site, based on mean data from the 3 sampling nccasions. Abbreviations for different treatments are presented in Table 3. The results of the SNK multiple comparison tests are presented for juveniles which recorded significant treatment effects following site-specific ANOVAs (Table 5). Levels of factors are ranked in decreasing order of abundance from left to right with lines joining levels which cannot be considered significantly different 
est juvenile $M$. liliana densities associated with treatments with either no adult $M$. liliana or empty articulated M. liliana shells (Fig. 1). Juvenile Austrovenus stutchburyi were also significantly influenced by the manipulation of adult conspecifics or their empty shells (Table 5). However, multiple comparison tests did not indicate a monotonic response by these juveniles to increasing adult density (Fig. 1). Juvenile Nucula hartvigiana responded significantly to the treatments involving $M$. liliana and exhibited a pattern of density variation similar to that shown by juvenile $M$. liliana, in all but the empty shell addition treatments. Block effects were apparent for $M$. liliana and $A$. stutchburyi juveniles (Table 5).

The significant differences discussed above represent small changes in mean density of about 1 to 3 ind. core $^{-1}\left(1.8 \mathrm{~cm}^{2} \times 2 \mathrm{~cm}\right.$ depth). When these differences are represented as a proportion of the treatment mean, the smallest significant difference detected was due to the influence of adult Austrovenus stutchburyi on conspecific juveniles at the muddy-sand site (i.e. $50 \%$ ). The influence of adult Macomona liliana on $M$. liliana and Nucula hartvigiana juveniles resulted in proportional density changes of $81 \%$ and $54 \%$ respectively at the sandy site and of $81 \%$ and $98 \%$ respectively at the muddy-sand site. Table 6 shows the difference in the number of individuals per core we would have been able to detect, with a power of $80 \%$, for non-significant treatment effects. With the exception of the response of juvenile $M$. liliana to $A$. stutchburyi treatments at the sandy site, we had sufficient power to detect a change in mean density of $\leq 2$ individuals. In all cases $<100 \%$ change in mean density could have been detected.

\section{DISCUSSION}

The significant differences found in our experiment involved changes in mean density of between 27 and $217 \%$ (Fig. 1). However, these changes reflected small changes in the mean density of juveniles, of 1 to 3 ind. core $^{-1}\left(1.8 \mathrm{~cm}^{2} \times 2 \mathrm{~cm}\right)$. Where we could not identify a significant response, in most cases we had sufficient power $(80 \%)$ to identify changes of a similar magnitude to those responses that were significant (i.e. mostly $\leq 2$ ind core ${ }^{-1}$ ). As significant responses mostly resulted from a contrast between the high and zero densities of the adult bivalves, our experiment demonstrated only a modest influence of adults on juveniles. It is perhaps surprising that we can identify any treatment effects at all given these small differences in mean density between treatments and the potentially high rates of movement by juveniles, particularly at the sandy site associated with wind-wave sediment disturbance (Emerson \& Grant 1991, Commito et al. 1995, Cummings et al. 1995, Dolphin et al. 1995, Roegnar et al. 1995).

Our experimental manipulation of densities of adult Macomona liliana or their empty articulated shells resulted in a greater number of significant effects on the density of juvenile bivalves than did the manipulation of densities of adult Austrovenus stutchburyi or their empty articulated shells. The only significant response to the $A$. stutchburyi density manipulation in this study was a significant contrast between treatments with no adult $A$. stutchburyi and those with 12 adult $A$. stutchburyi at the muddy-sand site. It is difficult to interpret the ecological significance of this

Table 6. Analysis of the power of the site-specific ANOVAs to detect significant differences for those factors for which a significant response was not detected (see Table 5). Calculations are based on 3 degrees of freedom for the $F$-ratio numerator ( $u$ ), sample size $(n)$ of 15 and $\alpha=0.05$, following Cohen (1988). The difference in treatment means that could be detected, with a power of $80 \%$, is given in absolute numbers $(\delta)$ and as a proportion of the mean (p $\delta$ )

\begin{tabular}{|c|c|c|c|c|c|c|c|}
\hline \multirow[t]{2}{*}{ Site } & & \multicolumn{3}{|c|}{ Addition of Macomona liliana treatments } & \multicolumn{3}{|c|}{ Addition of Austrovenus stutchburyi treatments } \\
\hline & & $\begin{array}{l}\text { A. stutchburyi } \\
\text { juveniles }\end{array}$ & $\begin{array}{l}M \text {. Liliana } \\
\text { juveniles }\end{array}$ & $\begin{array}{l}\text { N. hartvigiana } \\
\text { juveniles }\end{array}$ & $\begin{array}{c}\text { A. stutchburyi } \\
\text { juveniles }\end{array}$ & $\begin{array}{l}\text { M. Liliana } \\
\text { juveniles }\end{array}$ & $\begin{array}{l}N . \text { hartvigiana } \\
\text { juveniles }\end{array}$ \\
\hline \multirow[t]{6}{*}{ Sandy } & Power & 80 & - & - & 80 & 80 & 80 \\
\hline & Effect size & 0.46 & - & - & 0.46 & 0.46 & 0.46 \\
\hline & Range & 1.072 & - & - & 1.072 & 1.072 & 1.072 \\
\hline & Common SD & 1.57 & - & - & 1.57 & 4.72 & 1.85 \\
\hline & $\delta$ & 1.7 & - & - & 1.7 & 5.1 & 2.0 \\
\hline & $\mathrm{p} \delta$ & 0.67 & - & - & 0.67 & 0.81 & 0.54 \\
\hline \multirow[t]{6}{*}{ Muddy-sand } & Power & 80 & - & - & - & 80 & 80 \\
\hline & Effect size & 0.46 & - & - & - & 0.46 & 0.46 \\
\hline & Range & 1.072 & - & - & - & 1.072 & 1.072 \\
\hline & Common SD & 1.67 & - & - & - & 0.82 & 0.47 \\
\hline & $\delta$ & 1.8 & - & - & - & 0.9 & 0.5 \\
\hline & $\mathrm{p} \delta$ & 0.50 & - & - & - & 0.81 & 0.98 \\
\hline
\end{tabular}


result. Thus our findings support the conclusion drawn from the literature by Olafsson et al. (1994) that adult/juvenile responses are less consistent amongst suspension-feeding than deposit-feeding infauna. Our experiment also did not reveal a major role in adult/juvenile interactions for empty articulated shells of either species. Thus it would appear that boundary flow modification by A. stutchburyi, from either the physical influence of the shells or the active effects of suspension feeding (Ertman \& Jumars 1988, Monismith et al. 1990, Andre et al. 1993, O'Riordan et al. 1993), did not generate significant adult/juvenile interactions.

Naturally, the density of Macomona liliana is spatially variable (Thrush et al. 1989) and the high density used in the experiment was chosen to reflect densities encountered in high density patches on the flats. The negative effect of high densities of adult $M$. liliana on juveniles at the sandy site supports the negative adult/juvenile interactions inferred in Thrush et al. (1994) to account for the low juvenile M. liliana densities found in shorebird exclusion experimental plots with high densities of adult $M$. liliana. The densitydependent inhibition of recruitment by the infaunal deposit-feeding $M$. liliana at the present site provides another species-specific case which corroborates the conclusions of 'Olafsson et al. (1994).

The most intriguing result of our study was the sitedependent response of both Macomona liliana and Nucula hartvigiana juveniles to density variations of adult $M$. liliana. Highest juvenile densities were associated with experimental treatments containing 20 adult $M$. liliana at the muddy-sand site (Fig. 1). However, at the sandy site, highest juvenile densities were found in treatments with no adult $M$. liliana. This suggests that habitat characteristics and/or juvenile densities influenced the outcome of the adult/juvenile interactions. With only 1 experimental site in each habitat, we can not attribute these differences specifically to the habitat rather than to chance. However, the consistent behaviour over the experimental blocks within each site and the very similar results obtained for both $M$. Liliana and $N$. hartvigiana juveniles give us some confidence in the generality of our results.

There are a variety of mechanisms that could explain the inverse effects of adult Macomona liliana in the 2 different habitats. Larvae or juveniles may have responded to some chemical cue (e.g. see Woodin 1986 , 1991), associated with the adult M. liliana, which was detected by juveniles in only 1 habitat. Alternatively, juvenile density may be differentially influenced by predators (e.g. Watzin 1983, Zobrist \& Coull 1992) or sediment disturbers (e.g Brenchley 1981, Rhoads \& Boyer 1982, Meadows \& Meadows 1991), depending on type of habitat. While neither of these mechanisms can be dismissed, other studies that have identified differences in bivalve adult/juvenile interactions dependent on sediment type have invoked hypotheses that involve bivalve feeding behaviour, hydrodynamics and/or sediment characteristics (Peterson 1982, 'Olafsson 1989, Ahn et al. 1993). Peterson (1982) demonstrated that the bivalve Protothaca staminea consistently decreased the density of conspecific recruits in a muddy habitat but not in a sandy habitat, probably as a result of higher hydrodynamic activity and sediment mobility at the sandy site masking effects. 'Olafsson (1989) found that the growth of juvenile Macoma balthica was decreased by adult conspecifics at a muddy-sand site, but not a wave-exposed sand site, and related this to site-specific differences in feeding behaviour. Although detailed observation of the feeding behaviour of $M$. liliana at our sites was not possible because of poor water clarity, we routinely observed feeding traces characteristic of $M$. liliana surface deposit feeding in both habitats. Ahn et al. (1993) proposed that bioturbation by Gemma gemma decreased the stability of muddy-sand sediments to account for sediment specific differences in adult/juvenile interactions amongst the bivalves G. gemma and Mercenaria mercenaria in laboratory tests.

Some of the mechanisms postulated in these studies may contain components that are relevant to the patterns observed in our study. In our study, surface deposit feeding by Macomona liliana, with its associated sediment disturbance and changes to sediment microtopography, may interact with site-dependent habitat features such as variations in food supply (Gray 1974, Snelgrove \& Butman 1994), sediment mobility/stability (Meadows \& Meadows 1991, Ahn et al. 1993, Best 1993) or feeding behaviour ('Olafsson 1989, Levinton 1991. Peterson \& Skilleter 1994).

As with many field experiments, our sampling strategy was unable to differentiate between settlement and post-settlement survivorship, and attempting to hypothesise explanations of the results based solely on post-settlement processes may not fully account for the observed results. Whatever the actual mechanism, consistent effects occurred over the $9 \mathrm{wk}$ of this study despite the temporal variation in the density of settling larvae (cf. Andre \& Rosenberg 1991). Further studies are needed to identify the actual mechanisms involved and, in particular, the interaction between post-settlement movement associated with hydrodynamic activity and local biological interactions.

The findings of this study, which are integrated over settlement, early post-settlement survivorship and mobility, emphasise the importance of making predictions on the outcome of local biological interactions that are constrained by habitat type. For species such as those used in this experiment, which are commonly 
found in a variety of habitats, this indicates the need to use caution when generalising about the outcome of ecological interactions. The changes in the direction of ecological interactions from the sandy site to the muddy-sand site suggest that subtle changes in ecological processes may result from changes in sedimentation or hydrodynamic regimes associated with the development of coastal and harbour environments.

Acknowledgements. We thank K. Mischewski for help with the fjeldwork, M. Taylor for help with laboratory analysis, and P. Legendre and B. McArdle for helping with the statistical analysis. Early drafts of the manuscript were improved by comments from A. H. Hines, M. Taylor, S. Turner, D. Morrisey, C. H. Peterson and anonymous reviewers

\section{LITERATURE CITED}

Ahn IY, Lopez G, Malouf R (1993) Effects of the gem clam Gemma gemma on the early post-settlement emigration, growth and survival of the hard clam Mercenaria mercenaria. Mar Ecol Prog Ser 99:61-70

Ambrose WG Ji (1984) Influence of residence on the development of a marine soft-bottom community. J mar Res 42 $633-654$

Andre C, Jonsson PR, Lindegarth M (1993) Predation on set.tling bivalves by benthic suspension ieeders: the role of hydrodynamics and behavıour. Mar I col Prog Ser 97: $183-192$

Andre C, Rosenberg R (1991) Adult-larval interactions in the suspension feeding bivalves Cerastoderma edule and Mya arenaria. Mar Ecol Prog Ser 71:227-234

Armonies W, Hellwig-Armonies M (1992) Passive settlement of Macoma balthica spat on tidal flats of the Wadden Sea and subsequent migration of juveniles. Neth J Sea Res 29 $371-378$

Baggerman B (1953) Spatfall and transport of Cardium edule L. Arch Neerl Zool 10:315-342

Best JL (1993) On the interaction between turbulent flow structure, sediment transport and bedform development: some considerations from recent experimental research. In: Clifford NJ, French JR, Hardisty J (eds) Turbulence perspectives on flow and sedıment transport. John Wiley \& Sons, Chichester, p 61 - 92

Beukema JJ (1973) Migration and secondary spatfall of Macoma balthica ( $L$.) in the western part of the Wadden Sea. Neth J Zool 23:356-357

Black R, Peterson CH (1988) Absence of preemption and interference competition for space between large suspension-feeding bivalves and smaller infaunal macroinvertebrates. J exp mar Biol Ecol 120:183-193

Brenchley GA (1981) Disturbance and community structure: an experimental study of bioturbation in marine soft-sediment environments. J mar Res 39:767-790

Butman CA (1987) Larval settlement of soft-sediment invertebrates: the spatial scales of pattern explained by active habitat selection and the emerging role of hydrodynamical processes. Oceanogr mar Biol A Rev 25:113-165

Butman CA, Grassle JP, Webb CM (1988) Substrate choices made by marine larvae settling in still water and flume flow. Nature 333:771-773

Cohen J (1988) Statistical power analysis for the behavioural sciences. Hove and London, Hillsdale, NJ
Commito JA, Currier CA, Kane LR, Reinsel KA, Ulm IM (1995) Dispersal dynamics of the bivalve Gemma gemma in a patchy environment. Ecol Monogr 65:1-20

Crowder MJ, Hand DJ (1990) Analysis of repeated measures. Chapman and Hall, New York

Cummings VJ, Pridmore RD. Thrush SF, Howitt JE (1993) Emergence and floating behaviours of post-settlement juveniles of Macomona liliana (Bivalvı: Tellinacea). Mar Behav Physiol 24:25-32

Cummings VJ, Pridmore RD, Thrush st, Hewitt JE (1995) Post-settlement movement by intertidal benthic macroinvertebrates: do common New Zealand species drift in the water column? NZ J mar Freshwat Res 29:59-67

Dolphin TJ, Hume TM, Parnell KE (1995) Sedimentary and oceanographic processes on a sand flat in an enclosed sea, Manukau Harbour, New Zealand. Mar Geol 128:169-181

Eckman JE (1985) Flow disruption by an animal-tube mimic affects sediment bacterial colonization. J mar Res 43: $419-435$

Elmgren R, Ankar S, Marteleur B, Ejdung G (1986) Adult interference with postlarvae in soft sediments: the Pontoporeia-Macoma example. Ecology 67:827-836

Emerson CW, Grant J (1991) The control of soft-shell clam (Mya arenaria) recruitment on intertidal sandflats by bedload sediment transport. Limnol Oceanogr 36:1288-1300

Ertman SC, Jumars P: (1988) Effects of bivalve siphonal currents on the settlement of inert particles and larvae. J mar Res 46:797-813

Folk RL (1968) Petrology of sedimentary rocks. Hemphilis Austin. TX

Gray JS (1974) Animal-sediment relationships. Oceanogr mar Biol A Rev 12:707-722

Green RH (1993) Application of repeated measures designs in environmental impact and monitoring studies. Aust $J$ Ecol 18:81-98

Hines AH, Posey MH, Haddon PJ (1989) Effects of adult suspension- and deposit-feeding bivalves on recruitment of estuarine infauna. Veliger 32:109-119

Huynh H, Feldt LS (1976) Estimation of the Box correction for degrees of freedom from sample data in the randomised block and split plot designs. J Educ Stat 1:69-82

Levinton JS (1991) Variable feeding behaviour in 3 species of Macoma (Bivalvia: Tellinacea) a response to water flow and sediment transport. Mar Biol 110:375-383

Luckenbach MW (1987) Effects of adult unfauna on new recruits: implications for the role of biogenic refuges. $J$ exp mar Biol Ecol 105:197-206

Martel AS, Chia FS (1991) Driftıng and dispersal of small bivalves and gastropods with direct development. J exp mar Biol Ecol 150:131-147

Meadows PS, Meadow5 A (1991) The geotechnical and geochemical implications of bioturbation in marine sedimentary ecosystems. Symp zool Soc Lond 63:157-181

Mileikovsky SA (1969) About the relationship botween the breeding and spawning of marine bottom invertebrates with pelagic development and their interspatial relationships as adults in bottom communities and as larvae in the plankton. Limnologica 7:181-183

Monismith SG, Koseff JR, Thompson JK, O'Riordan CA, Nepf HM (1990) A study of model bivalve siphonal currents. Limnol Oceanogr 35:680-696

Muus K (1973) Settling, growth and mortality of young blvalves in the Orsund. Ophelia 12:79-116

'Olafsson EB (1989) Contrasting influences of suspensionfeeding and deposit feeding populations of Macoma balthica on infaunal recruitment. Mar Ecol Prog Ser 55: $171-179$ 
'Olafsson EB, Peterson CH, Ambrose WG Jr (1994) Does recruitment limitation structure populations and cornmunities of macroinvertebrates in marine solt sediments: the relative significance of pre- and post-settlement processes. Oceanogr mar Biol A Rev 32:65-109

O'Riordan CA, Monismith SG, Koseff JR (1993) A study of concentration boundary-layer formation over a bed of model bivalves. Limnol Oceanogr 38:1712-1729

Peterson CH (1982) The importance of predation and intraand interspecific competition in the population biology of 2 infaunal suspension-feeding bivalves, Protothaca staminea and Chione undatella. Ecol Monogr 52:437-475

Peterson CH. Andre SV (1980) An experimental analysis of interspecific competition among marine filter feeders in a soft sediment environment. Ecology 61:129-139

Peterson CH, Black R (1993) Experimental tests of the advantages and disadvantages of high density for 2 coexisting cockles in a Southern Ocean lagoon. J Anim Ecol 62: 614-633

Peterson CH, Skilleter GA (1994) Control of foraging behaviour of individuals within an ecosystem context: the clam Macoma balthica, flow environments dnd siphon-cropping fishes. Oecologia 100:256-267

Posey MH (1990) Functional approaches to sott-substrate communities: how useful are they? Rev aquat Sci 2:343-356

Pridmore RD. Thrush SF, Hewitt JE, Roper DS (1990) Macrobenthic community composition of six intertidal sandflats in Manukau Harbour, New Zealand. NZ J mar Freshwat Res 24:81-96

Rhoads DC, Boyer LF (1982) The effects of marine benthos on physical properties of sediments. A successional perspective. In: McCall PL, Tevesz MJS (ed) Anima!-sedirnent relations. Plenum Press, New York, p 3-52

Roegner $C$, Andre $C$, Lindegarth $M$, Eckman JE, Grant J (1995) Transport of recently settled soft-shell clams (Mya arenaria L.) in laboratory flume flow. J exp mar Biol Ecol $187: 13-26$

SAS (1989) SAS/STAT users quide, Version 6, 4th edn. SAS Institute Inc, Cary, NC:

This article was presented by C. H. Peterson (Senior Editorial Advisor), Morehead City, North Carolina, USA
Sigurdsson JB, Titman CW, Davies PA (1976) The dispersal of young post-larval bivaive molluscs by byssus threads. Nature 262:386-387

Snelgrove PVR, Butman CA (1994) Animal-sediment relationships revisited: cause versus effect. Oceanogr mar Biol A Rev 32:111-177

Tamaki A (1987) Comparison of resistivity to transport by wave action in several polychaete species on an intertidal sand flat. Mar Ecol Prog Ser 37:181-189

Thorson G (1950) Reproduction and larval ecology of marine bottom invertebrates. Biol Rev 25:1-45

Thrush SF, Hewitt JE, Pridmore RD (1989) Patterns in the spatial arrangement of polychaetes and bivalves in intertidal. sandflats. Mar Biol 102:529-536

Thrush SF, Pridmore RD, Hewitt JE, Cummings VJ (1991) Impact of ray feeding disturbances on sandflat macrobenthos do communities dominated by polychaetes or shellfish respond differently? Mar Ecol Pron Ser 69:245-252

Thrush SF, Pridmore RD. Hewitt JE, Cummings VJ (1994) The importance of predators on a sandflat: interplay between seasonal changes in prey densities and prodator effects. Mar Ecol Prog Ser 107:211-222

Watzin MC (1983) The effects of meiofauna on settling macrofauna: meiofauna may structure macrofaunal communities. Oecologia 59:163-166

Weinberg JR (1984) Interactions between functional groups in soft-substrate: do species differences matter? J exp mar Biol Ecol 80:11-28

Woodin SA (1974) Polychaete abundance patterns in a marine soft-sediment environment. The importance of biological interactions. Ecol Monogr 44:171-187

Woodin SA (1986) Settlement of infauna: larval choice? Bull mar Sci 39:401-401.

Woodin SA (1991) Recruitment of infauna: positive or negative cues? Am Zool 31:797-807

Zobrist EC, Coull BC (1992) Meiobenthic interactions with macrobenthic larvae and juveniles: an experimental assessment of the meiofaunal bottleneck. Mar Ecol Prog Ser $88: 1-8$

Manuscript first recejved: January 10, 1995

Revised version accepted: August 15, 1995 